\title{
Review: Pemanfaatan Teknik Kemometrika Pengenalan Pola Pada Analisis Kuantitatif Senyawa Obat Kombinasi Tanpa Tahap Pemisahan
}

\author{
Paulina N.F.P. Lorenza, Angelina K. Pandhita, Desy N.R.P. Mahemba, Arya P.N. Pede, \\ Theodora D.G. Seran, Dewi Setyaningsih, dan Florentinus D.O. Riswanto
}

Fakultas Farmasi Universitas Sanata Dharma, Yogyakarta, Indonesia

Korespondensi: Florentinus D.O. Riswanto

Email: dikaocta@usd.ac.id

Submitted: 11-11-2021, Revised: 23-11-2021, Accepted: 20-12-2021

\begin{abstract}
ABSTRAK: Penjaminan mutu produk obat kombinasi salah satunya dilakukan melalui analisis kuantitatif. Teknik kemometrika menjadi salah satu alternatif pilihan pengenalan pola pada analisis kuantitatif senyawa obat kombinasi tanpa tahap pemisahan yang mudah diterapkan, sensitif, dan cukup terjangkau. Keunggulan teknik kemometrika seperti ini telah dibuktikan pada berbagai penelitian yang relevan. Tujuan artikel review ini adalah untuk mengetahui lebih lanjut pemanfaatan teknik kemometrika pengenalan pola pada analisis kuantitatif senyawa obat kombinasi tanpa tahap pemisahan. Penyusunan artikel review ini menggunakan metode penelusuran literatur ilmiah primer terbitan sepuluh tahun terakhir pada rentang 2011 hingga 2021. Hasilnya menunjukkan bahwa teknik kemometrika yang paling banyak diaplikasikan adalah PLS 78,95\% dengan instrumen tanpa tahap pemisahan yang paling banyak digunakan sebagai kombinasinya adalah spektrofotometer UV-Vis $84,21 \%$. Selain itu, campuran obat dari dua senyawa $71,05 \%$ pada berbagai golongan obat menjadi jumlah campuran yang paling banyak dianalisa dengan kombinasi teknik kemometrika dan instrumen analisis.
\end{abstract}

Kata kunci: kemometrika; pengenalan pola; analisis kuantitatif tanpa tahapan pemisahan

\begin{abstract}
One of the quality assurance of combination drug products is done through quantitative analysis. The chemometric technique is an alternative choice for pattern recognition in the quantitative analysis of combination drug compounds without a separation step that is easy to apply, sensitive, and quite affordable. The superiority of this chemometric technique has been demonstrated in various relevant studies. The purpose of this review article is to find out more about the use of pattern recognition chemometric techniques in quantitative analysis of combined drug compounds without separation. The preparation of this review article uses the primary scientific literature search method published in the last ten years in the range of 2011 to 2021. The results show that the most widely applied chemometric technique is PLS 78.95\% with instruments without a separation stage the most widely used as a combination is UV-spectrophotometer. Vis $84,21 \%$. In addition, drug mixtures of two compounds $71.05 \%$ in various drug classes were the most widely analyzed mixtures using a combination of chemometric techniques and analytical instruments.
\end{abstract}

Keywords: chemometrics; pattern recognition; quantitative analysis without separation steps 


\section{Pendahuluan}

Obat yang beredar di pasaran sebagian besar dibuat dalam bentuk kombinasi beberapa bahan aktif, yang bertujuan untuk meningkatkan efek terapi obat dan memudahkan penggunaannya (1). Sebagai jaminan mutu suatu produk obat, diperlukan suatu metode analisis, salah satunya analisis kuantitatif untuk mengetahui kadar senyawa obat dalam sampel (misalnya dalam sediaan tablet yang mengandung campuran zat aktif) atau untuk mengetahui tingkat kemurnian suatu bahan obat. Pemeriksaan mutu ini dilakukan agar kadar komposisi obatnya sesuai dengan jumlah yang ditetapkan (sesuai dengan yang dituliskan pada kemasan), mengikuti prosedur analisis standar, serta dapat menunjang keamanan dan efek terapeutik yang diharapkan $(2,3)$.

Analisis kuantitatif dapat dilakukan secara klasik dan modern, dimana contoh metode klasik yang digunakan adalah metode titrimetri dan kromatografi cair kinerja tinggi. Metode titrimetri disukai karena biaya yang diperlukan relatif murah, namun memerlukan waktu analisis yang lama dan kurang sensitif untuk penentuan zat yang kadarnya kecil. Sedangkan metode kromatografi cair kinerja tinggi memiliki sensitivitas analisis yang tinggi, namun memerlukan biaya yang relatif mahal (3). Seiring dengan semakin berkembangnya ilmu pengetahuan, metode analisis kuantitatif pada analisis senyawa campuran juga semakin banyak dikembangkan. Salah satu metode analisis kuantitatif modern yang sudah semakin banyak digunakan adalah metode kemometrik.

Kemometrika merupakan ilmu yang memperoleh data dengan menerapkan metode matematika dan statistik. Kemometrika digunakan untuk mengumpulkan dan menganalisis data multivariat protokol, kalibrasi, memodelkan proses, mengenali pola dan klasifikasi, koreksi dan kompresi sinyal, serta mengendalikan proses statistic (4). Teknik kemometrika menjadi solusi yang baik untuk menganalisa senyawa campuran yang memiliki profil spektra tumpang tindih (5).
Terdapat berbagai jenis teknik kemometrik, dimana yang paling banyak digunakan misalnya principal component regression (PCR) (1), partial least squares (PLS) (6), inverse least squares (ILS), classical least square (CLS) (7), dan artificial neural network (ANN) (8). Penggunaan teknik kemometrika ini banyak dikombinasikan dengan berbagai macam instrumen analisis pada analisis kuantitatif obat/senyawa campuran seperti spektrofotometer UV-Vis, HPLC, fourier transform infrared (FTIR), dan near infrared spectroscopy technique (NIR) (9).

Kelebihan teknik analisis kuantitatif kemometrika adalah senyawa campuran dapat dianalisis tanpa prosedur pemisahan, tekniknya sangat mudah diterapkan, sangat sensitif, bermanfaat, serta sangat murah dibandingkan dengan analisis lainnya (10). Kelebihan ini juga telah dibuktikan, salah satunya oleh (7) melalui penelitiannya menggunakan kombinasi kemometrika (PLC, PCR, dan ILS) dengan instrumen spektrofotometer pada analisis campuran etodolac dan thiocolchicoside tanpa adanya proses pemisahan menyatakan bahwa dengan adanya kemometrika ini pengerjaan menjadi cepat, biaya murah, sederhana, serta dapat dipercaya untuk dilakukan di laboratorium kendali mutu sebagai alternatif metode yang ada. Oleh sebab itu, disusunlah review artikel ini untuk mengetahui lebih lanjut pemanfaatan teknik kemometrika pengenalan pola pada analisis kuantitatif senyawa obat kombinasi tanpa tahap pemisahan, agar dapat memberikan alternatif metode penetapan kadar yang dapat diterapkan pada analisis senyawa multikomponen lain yang belum pernah diteliti sebelumnya.

\section{Metode}

Metode penyusunan artikel review ini menggunakan penelusuran literatur ilmiah primer terbitan tahun 2011-2021, melalui pencarian pada Google, Google scholar, dan Pubmed (boolean logic) dengan menggunakan kata kunci yakni "Kemometrika", "Pengenalan Pola", "Analisis Kuanti- 
tatif Senyawa Obat Kombinasi”, "Analisis Kuantitatif Senyawa Obat Kombinasi Tanpa Tahap Pemisahan" dalam bahasa Inggris dan Indonesia. Pustaka yang digunakan berasal dari jurnal internasional dan jurnal nasional. Kriteria inklusi literatur yang digunakan ialah jurnal yang membahas tentang penerapan penggunaan kombinasi teknik kemometrika dengan instrumen analisis tanpa tahap pemisahan terbitan tahun 20112021. Kriteria eksklusi literatur yang digunakan ialah artikel penelitian yang tidak dapat diakses dengan lengkap. Alur penelusuran literatur dilakukan melalui beberapa langkah yaitu 1) menyusun latar belakang dan tujuan, 2) melakukan pencarian literatur ilmiah yang sesuai, 3) melakukan seleksi pada literatur yang telah diperoleh.

\section{Pembahasan}

Senyawa kombinasi adalah produk yang terdiri dari kombinasi obat dua atau lebih komponen yang secara fisik, kimia, atau dengan cara lain digabungkan atau dicampur dan diproduksi sebagai satu kesatuan (11). Pengenalan pola senyawa obat kombinasi pada analisis kuantitatif identik dengan penggunaan teknik kromatografi sebagai metode klasik, dimana metode ini unggul dalam hal identifikasi dan spesifisitas (12). Di sisi lain, instrumentasi HPLC juga dapat menghasilkan beberapa kesalahan yang berasal dari kondisi injeksi yang berbeda, fluktuasi bentuk dan area puncak, kebisingan, serta dari sumber lainnya. Namun, saat ini sudah semakin banyak diterapkan teknik kemometrika sebagai pendekatan metode modern yang digunakan untuk mengatasi kelemahan yang ditemui pada metode klasik (13). Teknik ini berhasil diterapkan untuk kontrol kualitas sampel campuran dengan keuntungan dalam aspek efektivitas waktu (cepat), efektivitas biaya (relatif lebih murah), dan langkah persiapan sampel minimum (mudah). Hasil yang diperoleh juga memiliki akurasi dan perolehan yang baik, dapat direproduksi, serta secara statistik tidak berbeda dari metode kromatografi, sehingga dapat digunakan sebagai metode alternatif dalam analisis rutin $(13,14)$.

Kemometrika dideskripsikan sebagai ilmu yang menghubungkan pengukuran kimiawi, yang dilakukan pada sistem kimia dengan instrumen dan luaran yang diinginkan (misalnya spektroskopi dan konsentrasi) melalui penerapan metode matematika atau statistik. Secara umum, metode kemometrika sangat cocok untuk analisis simultan beberapa senyawa yang mengalami tumpang tindih spektra dan tidak memungkinkan untuk menentukan konsentrasi setiap senyawanya melalui persamaan regresi linier klasik $(7,15)$. Perkembangan teknologi komputer telah menyebabkan pesatnya pertumbuhan kemometrika karena sebagian besar metode multivariat yang digunakan dalam kemometrika bergantung pada kemampuan komputer untuk melakukan perhitungan data yang diperoleh dengan metode kemometrika $(16,17)$.

Terdapat beberapa jenis teknik kemometrika yang selanjutnya diklasifikasikan oleh Miller dan Miller (2010) diantaranya principal component analysis (PCA), cluster analysis (CA), linear discriminant analysis and canonical variate analysis, K-nearest neighbour (KNN), disjoint class modelling, multiple linear regression (MLR), principal component regression (PCR), partial leastsquares (PLS) regression, dan artificial neural networks (ANN). Pada analisis kuantitatif, teknik kemometrika tersebut diaplikasikan bersamaan dengan berbagai instrumen misalnya spektrofotometer UV-Visible, spektrofotometer NIR, spektrofotometer fluoresensi, kromatografi cair, dan juga berbagai aspek kimia analitik lainnya seperti analisis injeksi aliran dalam sediaan farmasi (17). Dari hasil studi literatur (Tabel 1), pemanfaatan kombinasi teknik kemometrika dengan berbagai instrumen yang sudah semakin banyak digunakan sebagai pengenalan pola pada metode analisis kuantitatif senyawa obat kombinasi tanpa tahap pemisahan dijabarkan sebagai berikut.

\subsection{Classical Least Square (CLS)}

CLS adalah salah satu metode yang paling 
Tabel 1. Aplikasi teknik kemometrika pengenalan pola pada analisis kuantitatif senyawa obat kombinasi

\begin{tabular}{|c|c|c|c|c|}
\hline No & $\begin{array}{l}\text { Senyawa obat kombinasi } \\
\text { yang dianalisis }\end{array}$ & $\begin{array}{l}\text { Teknik } \\
\text { kemometrik }\end{array}$ & $\begin{array}{l}\text { Teknik } \\
\text { instrumen }\end{array}$ & Referensi \\
\hline 1 & $\begin{array}{l}\text { Darunavir Ethanolate dan } \\
\text { Cobicistat }\end{array}$ & CLS dan PLS & Spektrofotometer UV-Vis & $(38)$ \\
\hline 2 & $\begin{array}{l}\text { Paracetamol dan Tolperison } \\
\text { Hidroklorida }\end{array}$ & CLS, PCR, dan PLS & Spektrofotometer UV-Vis & (39) \\
\hline 3 & $\begin{array}{l}\text { Fenilefrin HCL dan Ketorolak } \\
\text { Trometamin }\end{array}$ & CLS, PCR, dan PLS & Spektrofotometer UV-Vis & $(40)$ \\
\hline 4 & Avanafil dan Dapoxetin & CLS, PLS, PCR, dan NPLS & Spektrofotometer UV-Vis & $(41)$ \\
\hline 5 & $\begin{array}{l}\text { Bisoprolol, Hidroklorotiazid, } \\
\text { dan Ramipril }\end{array}$ & CLS, PCR, dan PLS & Spektrofotometer UV-Vis & (5) \\
\hline 6 & Sinarizine dan Dimenhidrinat & CRACLS, SRACLS, dan PLS & Spektrofotometer UV-Vis & $(26)$ \\
\hline 7 & Parasetamol dan Piroxicam & GA-PLS dan JK-PLSR & Spektrofotometer UV-Vis & $(42)$ \\
\hline 8 & $\begin{array}{l}\text { Olmesartan, Amlodipin, dan } \\
\text { Hidroklorotiazid }\end{array}$ & MCR-ALS dan CLS & Spektrofotometer UV-Vis & $(33)$ \\
\hline 9 & $\begin{array}{l}\text { Rifampicin, Isoniazid, } \\
\text { Pirazinamid, dan Ethambutol } \\
\text { HCL }\end{array}$ & PLS & FTIR & $(43)$ \\
\hline 10 & Ezetimibe dan Simvastatin & PLS & Spektrofotometer UV-Vis & $(44)$ \\
\hline 11 & Vildagliptin dan Metformin & PLSR & $\begin{array}{l}\text { ATR-FTIR, Spektrofotometer } \\
\text { UV-Vis }\end{array}$ & $(14)$ \\
\hline 12 & $\begin{array}{l}\text { Kloramfenikol dan Hidrokortison } \\
\text { Asetat }\end{array}$ & PLS & FTIRS & $(45)$ \\
\hline 13 & Amlodipin dan Atorvastatin & PLS-1 Regression dan ANN & $\begin{array}{l}\text { Spektrofotometer UV-Vis dan } \\
\text { IR }\end{array}$ & $(46)$ \\
\hline 14 & Ibuprofen dan Parasetamol & PLS & $\begin{array}{l}\text { Fourier Transform Infrared } \\
\text { (FTIR) }\end{array}$ & $(6)$ \\
\hline 15 & Parasetamol dan Kafein & PLS & NIR & $(29)$ \\
\hline 16 & $\begin{array}{l}\text { Rifampisin, Isoniazid, } \\
\text { Pirazinamid, dan Etambutol }\end{array}$ & PLS & NIR & $(30)$ \\
\hline 17 & Sofosbuvir dan Ledipasvir & PLS & Spektrofotometer UV-Vis & $(21)$ \\
\hline 18 & $\begin{array}{l}\text { Paracetamol, Guaifenesin, } \\
\text { Fenilefrin, dan P-Aminofenol }\end{array}$ & PLS & Spektrofotometer Uv-Vis & $(35)$ \\
\hline 19 & Suksinat dan Piridoksin HCL & PLS dan MCR-ALS & Spektrofotometer UV-Vis & $(32)$ \\
\hline 20 & Etodolak dan Thiocolchicoside & PLS, PCR, dan ILS & Spektrofotometer UV-Vis & (7) \\
\hline 21 & Amoksisilin dan Flukloksasilin & $\begin{array}{l}\text { PLS SRACLS, CRACLS, dan } \\
\text { ANNs }\end{array}$ & Spektrofotometer UV-Vis & $(47)$ \\
\hline 22 & Metformin HCL dan Gliklazida & PLS dan NAP/CLS & Spektrofotometer UV-Vis & $(36)$ \\
\hline 23 & Parasetamol dan Kafein & PLSR dan ANN & Spektrofotometer UV-Vis & $(48)$ \\
\hline 24 & $\begin{array}{l}\text { Metoprolol, Propanolol, dan } \\
\text { Amiloride }\end{array}$ & PLSR dan PCR & Spektrofotometer Fluoresensi & $(49)$ \\
\hline 25 & $\begin{array}{l}\text { Parasetamol, Propifenazon, dan } \\
\text { Kafein }\end{array}$ & PCR & Spektrofotometer UV-Vis & $(1)$ \\
\hline
\end{tabular}




\begin{tabular}{|c|c|c|c|c|}
\hline No & $\begin{array}{l}\text { Senyawa obat kombinasi } \\
\text { yang dianalisis }\end{array}$ & $\begin{array}{l}\text { Teknik } \\
\text { kemometrik }\end{array}$ & $\begin{array}{l}\text { Teknik } \\
\text { instrumen }\end{array}$ & Referensi \\
\hline 26 & Moksifloksasin dan Metronidazol & PCR dan PLS & Spektrofotometer UV-Vis & $(50)$ \\
\hline 27 & $\begin{array}{l}\text { Parasetamol Aceclofenac dan } \\
\text { Eperisone HCL }\end{array}$ & PCR dan PLS & Spektrofotometer UV-Vis & (51) \\
\hline 28 & Siprofloksasin dan Ornidazole & PCR dan PLS & Spektrofotometer UV-Vis & $(52)$ \\
\hline 29 & $\begin{array}{l}\text { Cinitapride Hydrogen Tartrate } \\
\text { dan Pantoprazole Sodium }\end{array}$ & PCR dan PLS & Spektrofotometer UV-Vis & (53) \\
\hline 30 & Parasetamol dan Metoklopramid & PCR dan PLS & Spektrofotometer UV-Vis & $(54)$ \\
\hline 31 & $\begin{array}{l}\text { Tolperisone Hidroklorida dan } \\
\text { Natrium diklofenak }\end{array}$ & PCR dan PLS & Spektrofotometer UV-Vis & $(55)$ \\
\hline 32 & Diacerein dan Selekoksib & PCR dan PLS & Spektrofotometer UV-Vis & $(28)$ \\
\hline 33 & $\begin{array}{l}\text { Verapamil Hidroklorida dan } \\
\text { Gliklazida }\end{array}$ & PCR dan PLS & Spektrofotometer UV-Vis & $(22)$ \\
\hline 34 & $\begin{array}{l}\text { Betametason Dipropionat, } \\
\text { Klotrimazol and Benzil Alkohol }\end{array}$ & PCR, PLS, dan ANN & Spektrofotometer UV-Vis & $(46)$ \\
\hline 35 & Kafein dan Parasetamol & PCR, PLS, dan ANN & Spektrofotometer UV-Vis & $(8)$ \\
\hline 36 & $\begin{array}{l}\text { Parasetamol, Difenhidramin, } \\
\text { Kafein, dan Fenilefrin }\end{array}$ & PCR dan PLSR & Spektrofotometer UV-Vis & $(56)$ \\
\hline 37 & $\begin{array}{l}\text { Parasetamol, Klorzoksazon, dan } \\
\text { Ibuprofen }\end{array}$ & PCR dan PLS & Spektrofotometer UV-Vis & (57) \\
\hline 38 & Timolol dan Travoprost & CLS, PCR, dan PLSR & Spektrofotometer UV-Vis & (58) \\
\hline
\end{tabular}

Keterangan: ANN: Artificial Neural Networks; CLS: Classical Least Square; CRACLS: Concentration Residual Augmented Classical Least Squares; GA-PLS: Genetic Algorithm Partial Least Square; ILS: Inverse Least Squares; JK-PLSR: Jack-Knife Partial Least Square Regression; MCR-ALS: Multivariate Curve Resolution-Alternative Least Squares; NAP/CLS: Net Analyte Preprocessing combined with Classical Least Square; NPLS: N-way Partial Least-Squares; PCR: Principal Component Regression; PLS: Partial Least Square; PLSR: Partial Least Square Regression; dan SRACLS: Spectral Residual Augmented Classical Least Squares

sederhana, berdasarkan hubungan linier antara absorbansi dan konsentrasi komponen pada setiap panjang gelombang (18). CLS melibatkan penerapan MLR pada persamaan konvensional hukum spektroskopi Lambert-Beer. Salah satu keunggulan metode CLS adalah dapat digunakan untuk campuran analit yang komposisinya belum diketahui (17).

\subsection{Principal Component Regression (PCR)}

PCR adalah model yang banyak digunakan untuk data yang memiliki derajat kovarians yang besar dalam variabel independen atau ketika ada matriks yang tidak dikondisikan (17). PCR dikenal sebagai kombinasi dari analisis komponen utama PCA dan ILS untuk membentuk model kuantitatif untuk sampel yang kompleks (7). Prinsip dasar dari PCR adalah untuk mengurangi jumlah variabel prediktor dengan menggunakan beberapa komponen utama pertama dari pada variabel aslinya. Metode ini bekerja baik ketika ada tingkat korelasi yang cukup besar antara variabel-variabel prediktor. Biasanya hal ini terjadi pada kalibrasi terbalik. Dalam hal ini hanya beberapa komponen utama yang diperlukan untuk menggambarkan sebagian besar variasi dalam data. Komponen utama ini tidak berkorelasi. PCR juga merupakan teknik yang berguna ketika variabel prediktor sangat berkorelasi. Hal ini dapat menyebabkan masalah komplikasi matematis dengan MLR, menghasilkan prediksi yang tidak dapat diandalkan (19). Metode PCR 
bisa digunakan dalam mengatasi masalah multikolinier. Metode ini akan menghasilkan komponen-komponen utama yang tidak berkorelasi. Hal yang perlu diperhatikan ialah jika seluruh komponen utama diikutsertakan dalam model regresi, model yang dihasilkan akan sama dengan yang diperoleh dengan metode kuadrat terkecil. Jika hanya beberapa komponen utama saja yang diikutsertakan, maka akan diperoleh penduga koefisien regresi yang bias namun memiliki varian yang minimum (20).

\subsection{Partial Least Square (PLS)}

PLS kadang-kadang disebut regresi kuadrat terkecil parsial (PLSR) dan merupakan teknik dekomposisi spektral kuantitatif. Partial Least Squares (PLS) adalah salah satu contoh terbaik dari metode kemometrika yang diterapkan untuk mengkuantifikasi target secara berkala karena kemampuannya untuk mengatasi beberapa masalah seperti interaksi, band overlap dan colinearity. Dalam teknik ini, data spektral dan konsentrasi digunakan untuk dekomposisi data (21). Regresi PLS memiliki keunggulan memiliki data yang lebih cepat dengan nilai konsentrasi dan absorbansi analit yang menunjukkan spektrum tumpang tindih yang kuat, kesalahan dalam model kalibrasi (22).

Metode regresi PLS saling terkait dengan PCR dan MLR dimana PCR akan menemukan faktor-faktor yang akan menangkap sebagian besar varians dalam data sebelum regresi untuk variabel konsentrasi sementara MLR akan mengkorelasikan data dan konsentrasinya. Metode ini akan mencoba memaksimalkan kovarians sehingga mengkorelasikan varians dan data bersama-sama. Dekomposisi data dilakukan dengan menggunakan data spektral dan konsentrasi. PLS membutuhkan lebih sedikit variabel laten daripada PCR tetapi ini tidak akan mempengaruhi kemampuan prediksi metode. Dalam rangka untuk membuat estimasi yang baik dari parameter tambahan menjadi perlu untuk mengukur sejumlah besar sampel di bawah berbagai kondisi yang berubah (17).

\subsection{N-way Partial Least-Squares (NPLS)}

NPLS adalah algoritma dari keluarga PLS yang disesuaikan dengan data multimodal (variabel tensor). Tensor, atau array multi-arah, adalah generalisasi vektor dan matriks orde tinggi. NPLS memodelkan hubungan linier antara variabel input dan output berdasarkan tensor pengamatan. Dimensi pertama dari array sesuai dengan titik pengamatan, sedangkan dimensi lain terkait dengan mode analisis (misalnya, waktu, frekuensi, dan ruang). NPLS memiliki kelebihan yaitu peningkatan stabilitas, ketahanan terhadap kebisingan dan interpretasi hasil yang intuitif (23) dan kekurangannya yaitu tingkat konvergensi yang lambat ketika berhadapan dengan data tensorial orge tinggi (24). Untuk memproyeksikan data ke dalam ruang fitur dimensi rendah, NPLS menggunakan dekomposisi tensor dengan satu set proyektor yang sesuai dengan setiap modalitas (25).

\subsection{Concentration Residual Augmented Classical Least Squares (CRACLS)}

CRACLS adalah modifikasi untuk CLS tradisional untuk mengatasi kelemahannya dan memberikan hasil yang sebanding dengan yang diperoleh oleh PLS sambil menjaga keunggulan CLS dari prediktabilitas kualitatif yang baik dari estimasi profil komponen murni. Dalam CRACLS; CLS tradisional diterapkan dan matriks koefisien dihitung dan digunakan untuk mendapatkan dan estimasi baru untuk matriks konsentrasi. Matriks residu konsentrasi kemudian dihitung dan baris jumlah kuadrat tertinggi digunakan untuk menambah matriks konsentrasi awal secara iteratif. RMSEV dihitung setelah setiap iterasi dan model yang digunakan adalah dengan jumlah iterasi minimum tidak menunjukkan perbedaan yang signifikan dengan model yang dibangun dengan iterasi RMSEV minimum (26). CRACLS memiliki keunggulan dibandingkan SRACLS karena mampu memperkirakan profil spektral murni dari komponen yang dipelajari dan karenanya dapat berguna tidak hanya untuk analisis kuantitatif tetapi juga 
penentuan kualitatif dari masing-masing komponen yang dipelajari (27).

\subsection{Spectral Residual Augmented Classical Least Squares (SRACLS)}

SRACLS adalah modifikasi lain untuk CLS yang diperkenalkan untuk mengatasi kelemahan dan mempertahankan keuntungan dari prediktabilitas kualitatif yang baik. Dalam SRACLS, CLS tradisional diterapkan dan matriks koefisien dihitung dan digunakan untuk mendapatkan dan estimasi baru untuk matriks spectral (28).

\subsection{Genetic Algorithm Partial Least Square (GA-PLS)}

GA-PLS merupakan metode yang mampu menyaring sejumlah besar variabel, sehingga eliminasi/penambahan variabel bertahap (oleh JK-PLSR) dapat berlangsung lebih efisien (29). GA-PLS memiliki kelebihan yaitu dapat mengeksplorasi preprocessing secara paralel, cepat untuk beroperasi secara efisien pada beberapa versi dari data yang sama (30).

\subsection{Jack-Knife Partial Least Square Regression (JK-PLSR)}

JK-PLSR merupakan modifikasi untuk regresi PLS dan PCA yang digunakan untuk memilih variabel dengan menghitung perkiraan ketidakpastian yang terkait dengan koefisien regresi dan beban. Keuntungan metode ini dibandingkan Sparse PLSR adalah kecepatannya, karena didasarkan pada uji ketidakpastian dari koefisien regresi (31). Dalam (31) metode JK-PLSR berpotensi dalam menganalisis data spektroskopi, telah diidentifikasi bahwa memiliki kekurangan, dimana beberapa variabel yang tidak informatif tidak dibuang. Untuk memperbaiki cacat ini, kami menyarankan memperkenalkan parameter gangguan yang bertujuan menggembungkan varians ketidakpastian yang terkait dengan koefisien regresi. Setelah itu, dinilai apakah koefisien regresi tetap signifikan terlepas dari gangguan ini.

\subsection{Multivariate Curve Resolution-Alternative Least Squares (MCR-ALS)}

MCR-ALS adalah teknik kemometrika lain yang telah memungkinkan kuantifikasi sukses obat yang tumpang tindih secara spektral. Model PLS umum tidak hanya membutuhkan standar tetapi juga kemungkinan interferensi dalam bentuk sediaan untuk diketahui. Namun, ini tidak diperlukan bila menggunakan MCR-ALS, yang memiliki keuntungan menganalisis formulasi farmasi dengan eksipien yang tidak diketahui (32). Metode MCR-ALS yang dikembangkan memiliki keunggulan dalam memprediksi profil spektral murni obat dan juga pengaruh komponen pengganggu dalam bentuk sediaan (32). MCR-ALS memiliki sifat kualitatif yang tinggi (memberikan spektrum murni dari setiap komponen) tetapi penerapannya pada analisis farmasi kuantitatif terbatas (33).

\subsection{Artificial Neural Networks (ANN)}

ANN pertama kali dirancang untuk menduplikasi fungsi otak manusia, yang terdiri dari sejumlah unit pemrosesan sederhana yang dihubungkan oleh interkoneksi tertimbang yang dapat dimodifikasi (17). ANN akan menghitung konsentrasi untuk setiap training set, dan setiap perbedaan antara output dan konsentrasi yang diketahui akan digunakan untuk menyesuaikan parameter internal. Langkah-langkah prediksi dan penyesuaian ini diulang sampai tingkat akurasi yang diperlukan tercapai dan dievaluasi dengan satu set tes. Karena training set dan pengujian pasti akan berbeda sampai batas tertentu, penting untuk tidak menyesuaikan training set secara berlebihan, jika tidak, sistem tidak bekerja dengan baik pada set pengujian, dan selanjutnya sampel 'tidak diketahui' (19).

Tidak seperti metode MLR, PCR, dan PLS, ANN tidak mengasumsikan hubungan matematis awal antara variabel input dan output, sehingga sangat berguna ketika model matematika yang mendasarinya tidak diketahui atau tidak pasti (19). Selain itu, jika dibandingkan dengan MLR, ANN memiliki metode pemodelan yang lebih fleksibel karena fungsi linier dan nonlinier dapat digabungkan dalam unit pemrosesan yang memungkinkan hubungan yang lebih kompleks antara ruang deskriptor berdimensi tinggi dan data yang 
diberikan, ini pada gilirannya mengarah pada prediksi yang lebih baik. Kerugian utama metode ANN ini adalah model infrastrukturnya kompleks. Selain itu, untuk mendapatkan kalibrasi yang kuat, jumlah sampel harus lebih besar dari jumlah bobot yang akan diestimasi, artinya sampel kalibrasi yang digunakan jumlahnya banyak (17).

\subsection{Principal Component Analysis- Artificial Neural Networks (PCA-ANN)}

ANN adalah sejenis metode kecerdasan yang ditiru, yang terdiri dari sejumlah besar simpul sederhana yang sangat saling berhubungan atau neuron buatan yang meniru sistem saraf biologis nyata dalam menemukan hubungan input dan output. Secara teratur, jaringan saraf dilatih, sehingga input tertentu memberi petunjuk ke output target yang pasti. Biasanya banyak pasang input/target yang digunakan untuk pelatihan jaringan. ANN lebih unggul dibandingkan metode multivariat konvensional lainnya untuk memodelkan hubungan linier dan nonlinier variabel.

Kombinasi teknik matematika memberikan hasil yang lebih baik dibandingkan menggunakan penerapan metode tunggal. Dalam beberapa tahun terakhir, teknik berdasarkan analisis komponen utama dan jaringan saraf tiruan (PCA-ANN) telah diusulkan sebagai alat untuk memprediksi data kompleks atau nonlinier serta interferensi interaksi (34). PCA-ANN disarankan untuk memprediksi konsentrasi analit yang sesuai, di mana data spektrofotometer, diekspos ke PCA dan didekomposisi menjadi skor PC sebelum membangun model ANN. Nomor node input dipilih sebagai jumlah skor PC yang optimal. Pemilihan penambahan PCA sangat penting untuk meningkatkan hasil yang diperoleh dari metode ANN yang berbeda(35).

\subsection{Inverse Least Squares (ILS)}

ILS juga dikenal sebagai kalibrasi matrix, karena menggunakan aplikasi MLR untuk membalikkan persamaan hukum Lambert-Beer spektroskopi. Salah satu keunggulan metode CLS adalah dapat digunakan untuk campuran analit yang komposisinya belum diketahui. Metode ILS dapat digunakan untuk analit kompleks yang tidak dapat ditangani oleh CLS. Namun pemilihan panjang gelombangnya sulit dilakukan dan memakan waktu, serta jumlah panjang gelombang bergantung pada jumlah sampel kalibrasi. Pada dasarnya sejumlah besar sampel diperlukan untuk kalibrasi yang akurat (17).

\subsection{Net Analyte Preprocessing combined with Classical Least Square (NAP/CLS)}

NAP/CLS adalah salah satu metode di bawah Net Analyte Signal (NAS) preprocessing. NAS adalah bagian dari sinyal yang berhubungan langsung dengan konsentrasi yang diprediksi oleh model kalibrasi. Dalam istilah matematika, ini adalah bagian dari spektrum yang ortogonal terhadap ruang yang direntang oleh spektrum semua analit kecuali satu. NAP-CLS dianggap lebih sederhana daripada model PLS karena didasarkan pada model CLS yang terkenal. Selain itu, prapemrosesan data sebelum langkah kalibrasi juga dapat meminimalkan efek variasi sistematis yang tidak memiliki hubungan dengan parameter yang diinginkan $(36,37)$.

Berdasarkan hasil studi literatur di atas, teknik kemometrika yang sering diaplikasikan adalah PLS dengan persentase 78,947\% dari keseluruhan literatur yang diperoleh (Gambar 1). Metode ini sering diaplikasikan karena mampu memaksimalkan kovarians sehingga dapat mengkorelasikan varians dan data secara bersamaan. Dalam PLS, variabel yang menunjukkan korelasi tinggi dengan variabel respon diberi bobot ekstra karena akan lebih efektif dalam prediksi. Dengan cara ini kombinasi linear dari variabel prediktor dipilih yang berkorelasi tinggi dengan variabel respon dan juga menjelaskan variasi variabel prediktor. Selain itu, PLS membutuhkan lebih sedikit variabel laten dibandingkan PCR tetapi tidak mempengaruhi kemampuan prediksi metode $(17,19)$.

Instrumen analisis diperlukan sebagai kombinasi teknik kemometrika sebagai pengenalan pola pada analisis kuantitatif senyawa obat kombinasi tanpa tahap pemisahan, dimana hasil 
studi literatur menunjukkan bahwa instrumen yang paling banyak digunakan sebagai kombinasi adalah spektrofotometer UV-Vis (Gambar 2). Instrumen ini banyak digunakan karena mampu menganalisis zat organik dan anorganik dalam jumlah banyak, selektif, memiliki ketelitian yang tinggi dengan kesalahan relatif sebesar 1\%-3\%, analisis relatif cepat dan tepat, dan dapat digunakan untuk menetapkan kuantitas zat yang sangat kecil. Selain itu, hasil yang diperoleh cukup akurat, dimana angka yang terbaca langsung dicatat oleh detektor serta tercetak dalam bentuk angka digital maupun grafik pola spektra (59). Kombinasi berbagai teknik kemometrika dan instrumen analisis dalam pengenalan pola pada analisis kuantitatif berhasil diaplikasikan pada berbagai senyawa obat campuran. Hasil studi literatur menunjukkan bahwa senyawa campuran yang terbukti dapat dianalisis merupakan senyawa campuran berbagai golongan obat (Tabel 2) yang terdiri dari dua senyawa kombinasi (biner) sebesar 71,05\%, tiga senyawa kombinasi (terner) sebesar 21,05\%, dan empat senyawa kombinasi (kuartener) sebesar 7,90\% (Gambar 3).

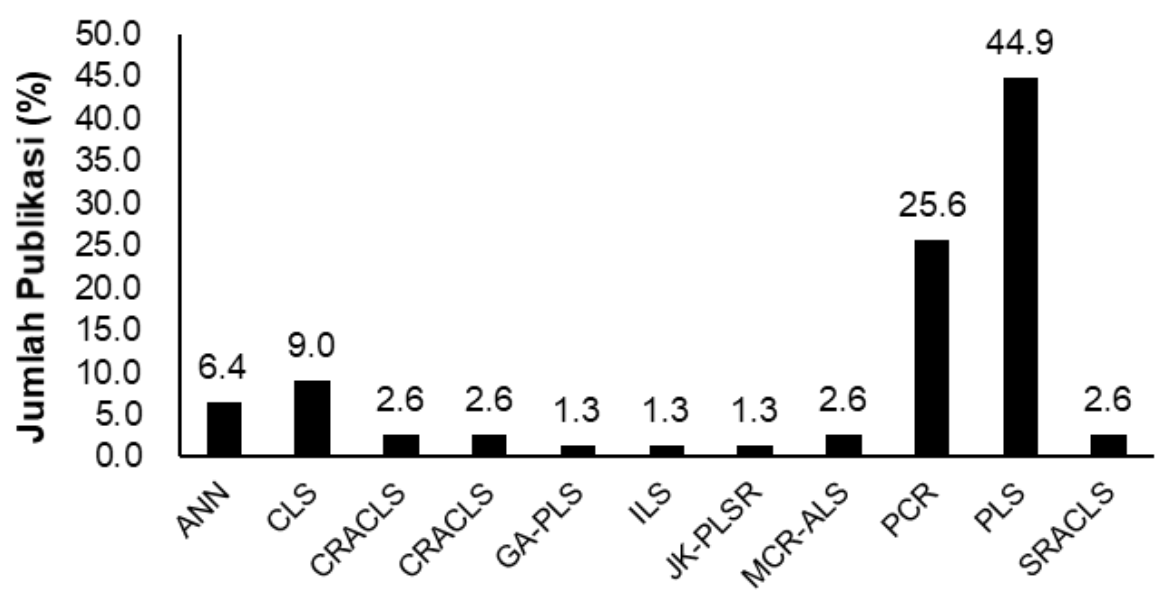

Teknik Kemometrika

Gambar 1. Persentase jumlah publikasi terkait teknik kemometrika

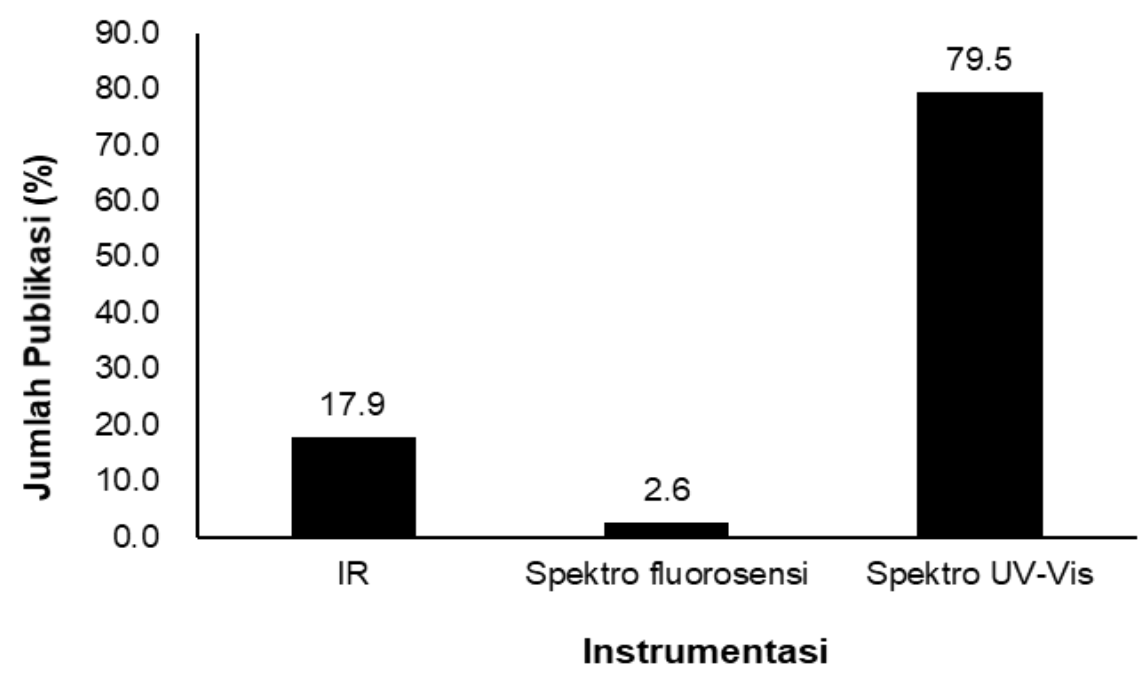

Gambar 2. Persentase instrumentasi yang digunakan pada publikasi terkait teknik kemometrika 


\section{Kesimpulan}

Konteks produk kombinasi yang perlu melalui analisa kuantitatif adalah produk yang terdiri dari dua atau lebih komponen. Analisa kuantitatif pada produk kombinasi ini dilakukan sebagai jaminan mutu produk agar kadar komposisi komponennya sesuai dengan jumlah yang ditetapkan (sesuai dengan yang dituliskan pada kemasan), mengikuti prosedur analisis standar, serta dapat menunjang keamanan dan efek terapeutik yang diharapkan. Analisa kuantitatif modern yang mudah, cepat, relatif murah, dan sensitif menjadi salah satu alternatif yang diharapkan oleh setiap industri farmasi pada analisis senyawa obat kombinasi, dimana teknik kemometrika dapat

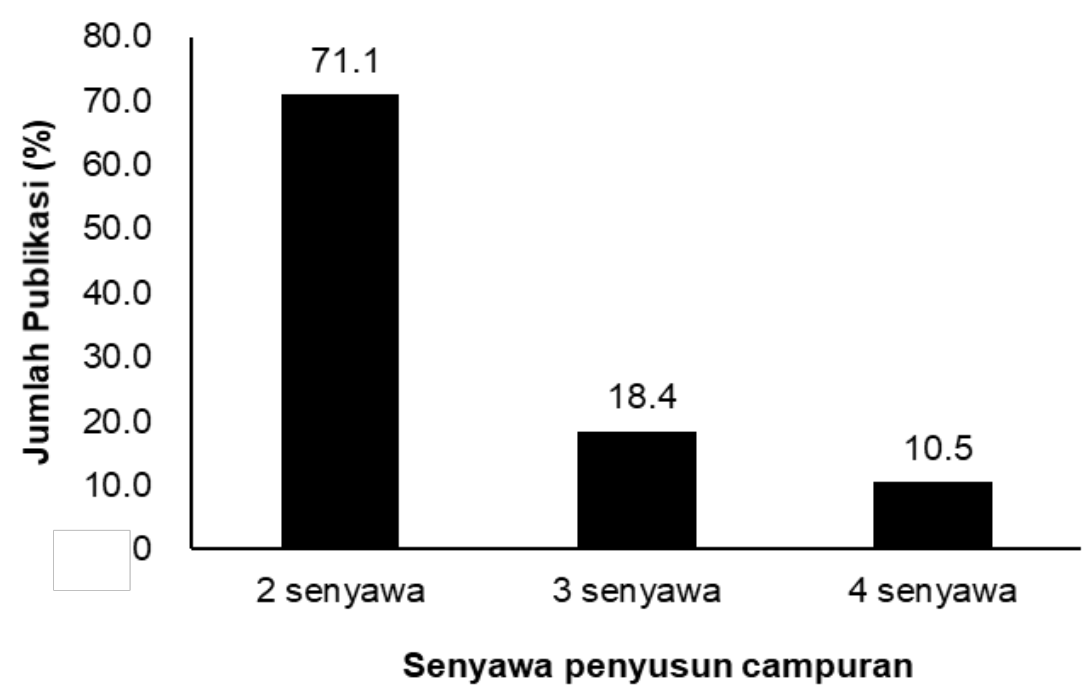

Gambar 3. Persentase jumlah senyawa dalam campuran pada publikasi terkait teknik kemometrika

Tabel 2. Golongan obat dalam campuran pada publikasi terkait teknik kemometrika

\begin{tabular}{lll}
\hline No & Nama obat & Golongan obat \\
\hline 1 & Darunavir Ethanolate dan Cobicistat & Anti HIV \\
\hline 2 & Paracetamol dan Tolperison Hidroklorida & Analgesik \\
\hline 3 & Fenilefrin HCL dan Ketorolak Trometamin & Cairan irigasi mata \\
\hline 4 & Avanafil dan Dapoxetin & Anti disfungsi ereksi \\
\hline 5 & Bisoprolol, Hidroklorotiazid, dan Ramipril & Antihipertensi \\
\hline 6 & Sinarizine dan Dimenhidrinat & Antivertigo \\
\hline 8 & Parasetamol dan Piroxicam & Analgesik \\
\hline 9 & Olmesartan, Amlodipin, dan Hidroklorotiazid & Antihipertensi \\
\hline 10 & Rifampicin, Isoniazid, Pirazinamid, dan Ethambutol HCL & Anti TBC \\
\hline 11 & Vildagliptin dan Metformin & Antidislipidemia \\
\hline 13 & Kloramfenikol dan Hidrokortison Asetat & Antidiabetes \\
\hline
\end{tabular}




\begin{tabular}{|c|c|c|}
\hline No & Nama obat & Golongan obat \\
\hline 14 & Ibuprofen dan Parasetamol & $\begin{array}{l}\text { Antiinflamasi, analgesik, dan } \\
\text { antipiretik }\end{array}$ \\
\hline 15 & Parasetamol dan Kafein & Analgesik \\
\hline 16 & Rifampisin, Isoniazid, Pirazinamid, dan Etambutol & Anti TBC \\
\hline 17 & Sofosbuvir dan Ledipasvir & Anti HCV \\
\hline 18 & Paracetamol, Guaifenesin, Fenilefrin, dan P-Aminofenol & Anti flu, batuk, dan pilek \\
\hline 19 & Suksinat dan Piridoksin HCL & Anti mual dan muntah \\
\hline 20 & Etodolak dan Thiocolchicoside & Analgesik \\
\hline 21 & Amoksisilin dan Flukloksasilin & Antibakteri \\
\hline 22 & Metformin HCL dan Gliklazida & Antidiabetes \\
\hline 23 & Parasetamol dan Kafein & Analgesik \\
\hline 24 & Metoprolol, Propanolol, dan Amiloride & Antihipertensi \\
\hline 25 & Parasetamol, Propifenazon, dan Kafein & Analgesik \\
\hline 26 & Moksifloksasin dan Metronidazol & Antibakteri \\
\hline 27 & Parasetamol, Aceclofenac dan Eperisone HCL & Analgesik dan Pelemas otot \\
\hline 28 & Siprofloksasin dan Ornidazole & Antibakteri \\
\hline 29 & Cinitapride Hydrogen Tartrate dan Pantoprazole Sodium & Anti GERD \\
\hline 30 & Parasetamol dan Metoklopramid & Analgesik dan Antiemetik \\
\hline 31 & Tolperisone Hidroklorida dan Natrium diklofenak & Analgesik dan Antiinflamasi \\
\hline 32 & Diacerein dan Selekoksib & Anti Osteoartritis \\
\hline 33 & Verapamil Hidroklorida dan Gliklazida & Antihipertensi dan Antidiabetes \\
\hline 34 & Betametason Dipropionat, Klotrimazol and Benzil Alkohol & Anti flu dan batuk \\
\hline 35 & Kafein dan Parasetamol & Analgesik \\
\hline 36 & Parasetamol, Difenhidramin, Kafein, dan Fenilefrin & Antipiretik, flu, batuk, dan anti alergi \\
\hline 37 & Parasetamol, Klorzoksazon, dan Ibuprofen & Analgesik dan antipiretik \\
\hline 38 & Timolol dan Travoprost & Penurunan Intraokular \\
\hline
\end{tabular}

menjadi salah satu pilihannya. Keuntungan penggunaan teknik kemometrika pada pengenalan pola analisis kuantitatif senyawa obat kombinasi tanpa tahap pemisahan telah banyak dibuktikan melalui berbagai macam penelitian dalam kurun waktu sepuluh tahun terakhir.

Dari hasil studi literatur dapat disimpulkan bahwa teknik kemometrika yang paling banyak diaplikasikan adalah PLS (78,95\%); instrumen tanpa tahap pemisahan yang paling banyak digunakan sebagai kombinasi teknik kemometrika adalah spektrofotometer UV-Vis $(84,21 \%)$; serta jumlah senyawa yang paling banyak dianalisa dengan kombinasi teknik kemometrika dan ins- 
trumen analisis adalah campuran obat yang terdiri dari dua senyawa $(71,05 \%)$ dari berbagai golongan obat.

\section{Keterbatasan artikel}

Review artikel ini hanya berfokus pada beberapa pemanfaatan teknik kemometrika pengenalan pola pada analisis kuantitatif senyawa obat kombinasi tanpa tahap pemisahan. Masih diperlukan studi literatur terkait aplikasi teknik kemometrika yang dikombinasikan dengan metode instrumentasi kimia analisis yang menghasilkan pemisahan seperti kromatografi cair, kromatografi gas, serta elektroforesis.

\section{Ucapan terima kasih}

Penulis mengucapkan terima kasih kepada Fakultas Farmasi Universitas Sanata Dharma sebagai institusi asal penulis dan semua pihak yang terlibat dalam penyusunan artikel review ini.

\section{Daftar pustaka}

1. Pulungan AF. Penentuan Campuran Parasetamol, Propifenazon dan Kofein Secara Spektrofotometri Ultraviolet Dengan Metode Principal Component Regression Dan Rasio Absorbansi Tahun 2018. JIFI (Jurnal Ilmiah Farmasi Imelda) 2019;2(2):82-8.

2. Cartika H. Modul Bahan Cetak Farmasi: Kimia Farmasi. Jakarta: Kementerian Kesehatan Republik Indonesia; 2016.

3. Sari AIN, Kuntari K. Penentuan Kafein dan Parasetamol dalam Sediaan Obat Secara Simultan Menggunakan Spektrofotometer UV-Vis. IJCA (Indonesian J Chem Anal. 2019;2(1):20-7.

4. Singh I, Juneja P, Kaur B, Kumar P. Pharmaceutical Applications of Chemometric Techniques. Hindawi. 2013;1-13.

5. Alahmad S, Elfatatry HM, Mabrouk MM, Hammad SF, Mansour FR. Chemometric Methods for Simul- taneous Determination of Bisoprolol, Hydrochlorothiazide and Ramipril in Ternary Combinations. Der Pharma Chem. 2018;10(3):140-5.

6. Mallah MA, Sherazi STH, Mahesar SA, Khaskheli AR. Simultaneous Quantification of Ibuprofen and Paracetamol in Tablet Formulations Using Transmission Fourier Transform Infrared Spectroscopy. Am J Anal Chem. 2012;3:503-11.

7. Albayrak M, Demirkaya-Miloglu F, Senol O, Polatdemir E. Design, optimization, and validation of chemometrics-assisted spectrophotometric methods for simultaneous determination of etodolac and thiocolchicoside in pharmaceuticals. J Anal Sci Technol. 2019;10(16):1-8.

8. Aktaş AH, Kitiş F. Spectrophotometric simultaneous determination of caffeine and paracetamol in commercial pharmaceutical by principal component regression, partial least squares and artificial neural networks chemometric methods. Croat Chem Acta. 2014;87(1):69-74.

9. Rahman A, Sravani GJ, Srividya K, Priyadharshni ADR, Narmada A, Sahithi K, et al. Development and Validation of Chemometric Assisted FTIR Spectroscopic Method for Simultaneous Estimation of Valsartan and Hydrochlorothiazide in Pure and Pharmaceutical Dosage Forms.J Young Pharm. 2020;12(2):s51-5.

10. Patel R, Mashru R. Development and Validation of Chemometric Assisted Methods and Stability Indicating RP-HPLC Method for Simultaneous Estimation of Rasagiline Mesylate and Pramipexole in Synthetic Mixture. Acta Sci Pharm Sci. 2019;3(8):154-68.

11. FDA. Combination Product FAQs. 2021.

12. Heneedak HM, Salama I, Mostafa S, El-Sadek M. HPLC and chemometric methods for the simultaneous determination of miconazole nitrate and nystatin. J Chromatogr Sci. 2012;50(10):855-61.

13. Aktas AH, Saridag AM. Liquid ChromatographicChemometric Techniques for the Simultaneous HPLC Determination of Lansoprazole, Amoxicillin and Clarithromycin in Commercial Preparation. $J$ Chromatogr Sci. 2017;55(8):798-804.

14. Eid SM, Soliman SS, Elghobashy MR, Abdalla OM. ATR-FTIR coupled with chemometrics for quanti- 
fication of vildagliptin and metformin in pharmaceutical combinations having diverged concentration ranges. Vib Spectrosc. 2020;106.

15. Rohman A, Windarsih A. The application of molecular spectroscopy in combination with chemometrics for halal authentication analysis: A review. Int J Mol Sci. 2020;21(5155):1-18.

16. Pawar HA. Chemometrics and its Application in Pharmaceutical Field. J Phys Chem Biophys. 2014;4(6):4-6.

17. Prajapati PR, Rathod DN, Modi VS, Basuri T. Chemometrics and its Applications in UV Spectrophotometry. Int J Pharm Chem Anal. 2016;3(1):43-8.

18. Bhamre P, Pathak A, Rajput S. SIMULTANEOUS DETERMINATION OF DOXYLAMINE SUCCINATE, PYRIDOXINE HYDROCHLORIDE AND FOLIC ACID BY. Int J Pharma Bio Sci. 2013;4(1):738-49.

19. Miller JN, Miller JC. Statistics and Chemometrics for Analytical Chemistry, 6th Ed. Harlow: Pearson Education Limited; 2010.

20. Ohyver M. PEMODELAN PRINCIPAL COMPONENT REGRESSION DENGAN SOFTWARE R. (9):177-85.

21. Khalili M, Sohrabi MR, Mirzabeygi V, Torabi Ziaratgahi N. Chemometric simultaneous determination of Sofosbuvir and Ledipasvir in pharmaceutical dosage form. Spectrochim Acta - Part A Mol Biomol Spectrosc. 2018;194:141-51.

22. Bhaskar R, Bhaskar R, Sagar MK, Saini V, Bhat K. Simultaneous Determination of Verapamil Hydrochloride and Gliclazide in Synthetic Binary Mixture and Combined Tablet Preparation by Chemometric-Assisted Spectroscopy. J Anal Sci Methods Instrum. 2012;2:161-6.

23. Zhao Q, Caiafa CF, Mandic DP, Chao ZC, Nagasaka Y, Fujii N. Higher-Order Partial Least Squares (HOPLS): A Generalized Multi-Linear Regression Method. :1-13.

24. Hou M, Zhao Q, Chaib-draa B, Cichocki A. Common and Discriminative Subspace Kernel-Based Multiblock Tensor Partial Least Squares Regression. 2016;1673-9.

25. Eliseyev A, Aksenova T. Recursive N-Way Partial Least Squares for Brain-Computer Interface. PLoS One. 2013;8(7).

26. Tawakkol SM, El-Zeiny MB, Hemdan A. Full spec- trum and selected spectrum based chemometric methods for the simultaneous determination of Cinnarizine and Dimenhydrinate in laboratory prepared mixtures and pharmaceutical dosage form. Spectrochim Acta - Part A Mol Biomol Spectrosc. 2017;1-27.

27. Hegazy MA, Abdelwahab NS, Ali NW, Sharkawi MMZ, Abdelkawy MM, El-Saadi MT. Comparison of two augmented classical least squares algorithms and PLS for determining nifuroxazide and its genotoxic impurities using UV spectroscopy. $J$ Chemom. 2019;1-12.

28. Ragupathy V, Arcot S. Simultaneous Spectrophotometric Determination of Diacerein and Celecoxib in Capsules By Chemometric Methods. Int Res J Pharm. 2013;4(6):229-33.

29. Muntean DM, Alecu C, Tomuta I. Simultaneous quantification of paracetamol and caffeine in powder blends for tableting by NIR-chemometry. Hindawi. 2017;1-8.

30. Teixeira KSS, da Cruz Fonseca SG, de Moura LCB, de Moura MLR, Borges MHP, Barbosa EG, et al. Use of chemometrics to compare NIR and HPLC for the simultaneous determination of drug levels in fixed-dose combination tablets employed in tuberculosis treatment. J Pharm Biomed Anal. 2018;149:557-63.

31. Karaman I, Qannari EM, Martens H, Hedemann MS, Knudsen KEB, Kohler A. Comparison of Sparse and Jack-knife partial least squares regression methods for variable selection. Chemom Intell $\mathrm{Lab}$ Syst. 2013;122(2013):65-77.

32. Katsarov P, Gergov G, Alin A, Pilicheva B, Al-Degs Y, Simeonov V, et al. Advanced spectrophotometric chemometric methods for resolving the binary mixture of doxylamine succinate and pyridoxine hydrochloride. Acta Pharm. 2018;68:61-73.

33. Darwish HW, Bakheit AH, Abdelhameed AS. Simultaneous quantitative analysis of olmesartan, amlodipine and hydrochlorothiazide in their combined dosage form utilizing classical and alternating least squares based chemometric methods. Acta Pharm. 2016;66(1):83-95.

34. Nakhaei F, Irannajad M, Mohammadnejad S. Column flotation performance prediction: PCA, 
ANN and image analysis-based approaches. 2019;5(55):1298-310.

35. Yehia AM, Mohamed HM. Chemometrics resolution and quantification power evaluation: Application on pharmaceutical quaternary mixture of Paracetamol, Guaifenesin, Phenylephrine and paminophenol. Spectrochim Acta - Part A Mol Biomol Spectrosc. 2016;152:491-500.

36. Bhaskar R, Bhaskar R, K Sagar M. UV-Spectrophotometric-Assisted Chemometric Methods for the Simultaneous Determination of Metformin Hydrochloride and Gliclazide in Pharmaceutical Formulations. Pharm Anal Acta. 2012;03(04).

37. Darwish HW, Naguib IA, Darwish IA. Five modified classical least squares based models for stability indicating analysis of cyclobenzaprine $\mathrm{HCl}$ with its major degradation products : A comparative study Spectrochimica Acta Part A : Molecular and Biomolecular Spectroscopy Five modi fi ed classical least squares based models for stability indicating analysis of cyclobenzaprine $\mathrm{HCl}$ with its major degradation products : A comparative study. 2018;(June).

38. Devi Singh V, Kumar Singh V. Chemo-metric assisted UV-spectrophotometric methods for simultaneous estimation of Darunavir ethanolate and Cobicistat in binary mixture and their tablet formulation. Spectrochim Acta - Part A Mol Biomol Spectrosc. 2021;250:119383.

39. Shah UH, Jasani AH. Chemometric assisted spectrophotometric methods for simultaneous determination of paracetamol and tolperisone hydrochloride in pharmaceutical dosage form. Eurasian J Anal Chem. 2017;12(3):211-22.

40. Elfatatry HM, Mabrouk MM, Hammad SF, Mansour FR, Kamal AH, Alahmad S. Development and validation of chemometric-assisted spectrophotometric methods for simultaneous determination of phenylephrine hydrochloride and ketorolac tromethamine in binary combinations. J AOAC Int. 2016;99(5):1247-51.

41. Patel MN, Kothari CS. Multivariate approaches for simultaneous determination of avanafil and dapoxetine by UV chemometrics and HPLC-QbD in binary mixtures and pharmaceutical product. $J$ AOAC Int. 2016;99(3):649-63.
42. Kambira PFA, Notario D, Gunawan U, Dhamayanti S, Ningrum RWK, Ambarita SGO, et al. Combination Uv-Vis Spectroscopy and Partial Least Square for Detecting Adulteration Paracetamol and Piroxicam in Traditional Medicines. J Pharm Sci Community. 2020;17(1):41-50.

43. Kurniati Z, Riyant S, Rohm A. Determination of Rifampicin, Isoniazid, Pyrazinamide and Ethambutol Hydrochloride in 4Fdc Tablet By Ftir Spectrophotometry in Combination With Multivariate Calibration. J Food Pharm Sci. 2016;4:25-30.

44. de Souza FH, Todeschini V, da Silva Sangoi M. Chemometric-assisted spectrophotometric method for the simultaneous quantitative determination of ezetimibe and simvastatin in their combined dosage forms. J AOAC Int. 2018;101(4):1015-20.

45. Khotimah K, Martono S, Windarsih A, Prihandiwati E. Application of FTIR Spectroscopy Combined with Multivariate Calibrations for Analysis of Chloramphenicol and Hydrocortisone Ace-tate in Cream Samples. Indones J Pharm. 2021;32(3):408-15.

46. Darwish HW, Elzanfaly ES, Saad AS, Abdelaleem AEB. Full spectrum and selected spectrum based multivariate calibration methods for simultaneous determination of betamethasone dipropionate, clotrimazole and benzyl alcohol: Development, validation and application on commercial dosage form. Spectrochim Acta - Part A Mol Biomol Spectrosc. 2016;1-26.

47. Attia KAM, Nassar MWI, El-Zeiny MB, Serag A. Effect of genetic algorithm as a variable selection method on different chemometric models applied for the analysis of binary mixture of amoxicillin and flucloxacillin: A comparative study. Spectrochim Acta - Part A Mol Biomol Spectrosc. 2016;156:54-62.

48. Uddin M, Mondol A, Karim M, Jahan R, Rana A. Chemometrics assisted spectrophotometric method for simultaneous determination of paracetamol and caffeine in pharmaceutical formulations. Bangladesh J Sci Ind Res. 2019;54(3):215-22.

49. Shinde MA, Divya O. Simultaneous quantitative analysis of a three-drug combination using synchronous fluorescence spectroscopy and chemo- 
metrics. Curr Sci. 2015;108(7):1348-54.

50. Ertokus GP, Celik UM. Chemometric Analysis of Moxifloxacin and Metronidazole in Binary Drug Combinations With Spectrophotometric Method. East Anatol J Sci. 2017;III(II):30-7.

51. Rathinam S, Santhana LK. Ecofriendly simple UV spectrophotometric and chemometric methods for simultaneous estimation of paracetamol aceclofenac and eperisone hydrochloride in pharmaceutical formulation: Assessment of greenness profile. Processes. 2021;9(8).

52. Gandhi S V, Waghmare AD, Nandwani YS, Mutha AS, College A, Road K. Chemometrics - Assisted UV Spectrophotometric Method for Determination of Ciprofloxacin and Ornidazole in Pharmaceutical Formulation. ARC J Pharm Sci. 2017;3(1):19-25.

53. Karanjia J. International Journal of Pharmaceutical Sciences and Drug Research CODEN ( USA ): IJPSPP Development and Validation of StabilityIndicating HPTLC Method for Simultaneous Determination of Telmisartan and Cilnidipine in Combined Tablet Dosage Form. Int J Pharm Sci Drug Res. 2015;7(2):198-204.

54. Ertokuş GP, Yildiz M. Chemometric Analysis of Paracetamol and metaclopromide in Binary Drug Combinations. Int J Pharm Sci Res. 2018;9(3):1268-73.

55. Gohel NR, Patel BK, Parmar VK. Chemometrics- assisted UV spectrophotometric and RP-HPLC methods for the simultaneous determination of tolperisone hydrochloride and diclofenac sodium in their combined pharmaceutical formulation. $S c i$ Pharm. 2013;81(4):983-1001.

56. Palur K, Archakam SC, Koganti B. Chemometric assisted UV spectrophotometric and RP-HPLC methods for simultaneous determination of paracetamol, diphenhydramine, caffeine and phenylephrine in tablet dosage form. Spectrochim Acta Part A Mol Biomol Spectrosc. 2020;243:118801.

57. Gandhi S V, Tapale SR. Chemometric-assisted UVspectrophotometric method for simultaneous estimation of paracetamol , chlorzoxazone and ibuprofen in multicomponent formulation. AshEses $J$ Pharm. 2016;1(1):1-8.

58. Salem H. Development and Validation of Novel Spectro- Chemometric, Chemometric and TLCDensitometric Methods for Simultaneous Determination of Timolol and Travoprost in their Bulk Powders and Pharmaceutical Formulation. Arch Pharm Pharmacol Res. 2019;2(1):1-11.

59. Rohmah SAA, Muadifah A, Martha RD. Validasi Metode Penetapan Kadar Pengawet Natrium Benzoat pada Sari Kedelai di Beberapa Kecamatan di Kabupaten Tulungagung Menggunakan Spektrofotometer Uv-Vis. J Sains dan Kesehat. 2021;3(2):120-7. 